\author{
Piotr Stańczyk \\ ORCID: 0000-0003-0124-2936 \\ Uniwersytet Ekonomiczny we Wrocławiu \\ piotr.stanczyk@ue.wroc.pl
}

\title{
Rozwój przedsiębiorczości w Polsce w ujęciu międzywojewódzkim
}

\author{
Artykuł nadesłany: 9.12.2019; artykuł zaakceptowany: 25.05.2020 \\ Kody klasyfikacji JEL: R13
}

Keywords: entrepreneurship, innovation, REGON register, financial results of business entities

\section{Abstract \\ The development of entrepreneurship in Poland in inter-voivodship terms}

The main purpose of the publication is to assess regional (inter-voivodeship) differences in the development of entrepreneurship in Poland in the light of the proposed set of indicators, calculated on the basis of statistical data collected by Statistics Poland.

Bearing in mind the availability of empirical data, it was assumed that the level of entrepreneurship development can be demonstrated by the values of indicators characterizing three basic dimensions of entrepreneurship: propensity to start a business, innovative activity and financial results, including export activity. These dimensions were analyzed in terms of time - from Poland's accession to the European Union to 2018.

During the analyzed period, financial indicators showed particularly dynamic characteristics (especially in the scope of export activity and gross financial result). At the same time, great diversity and a large degree of spatial concentration in terms of these characteristics were maintained.

The relation of newly-registered entities to de-registered entities in most voivodships was increasing, which may indicate a growing tendency to start their own business and, indirectly, also to increase the survival of companies on the market.

On the other hand, the propensity to invest in innovation in almost all voivodships decreased significantly over the years under study, while the large disproportion in terms of the amount of financial expenditure on innovation activities - the budget for innovation in enterprises - persisted among voivodships. On the other hand, the smallest degree of diversity across voivodships was recorded for the percentage of innovative enterprises and the percentage of enterprises that incurred expenditure on innovation. 


\section{Wstęp}

Celem artykułu jest ocena dysproporcji międzywojewódzkich w poziomie rozwoju przedsiębiorczości w latach 2004-2018 na podstawie zaproponowanego zestawu wskaźników, których wartości policzono, korzystając z danych GUS. Wybrany do analizy przedział czasowy to okres zmieniających się warunków i przeobrażeń w życiu społeczno-gospodarczym. Interesujące było zatem sprawdzenie na podstawie dostępnych danych statystycznych, czy w okresie członkostwa w Unii Europejskiej, umożliwiającego między innymi pozyskiwanie unijnych środków finansowych, w tym z różnych regionalnych (lub lokalnych) instrumentów wsparcia działalności, wykorzystano w regionach pojawiające się szanse sprzyjające rozwojowi przedsiębiorczości.

Przedsiębiorczość jest zagadnieniem bardzo obszernym, wieloaspektowym, o charakterze interdyscyplinarnym ${ }^{1}$. W węższym znaczeniu pojęcie przedsiębiorczości utożsamia się z aktywnością w zakresie działalności gospodarczej — z założeniem bądź prowadzeniem własnej firmy (w tym z zatrudnianiem pracowników). W znacznie szerszym kontekście przedsiębiorczość łączy się z działaniami osób przedsiębiorczych, osób o pewnych specyficznych kompetencjach społecznych, inteligentnych, innowacyjnych, kreatywnych, dostrzegających uwarunkowania i związki zachodzące między zjawiskami gospodarczymi, potrafiących wykorzystać pojawiające się szanse.

W literaturze naukowej, zwłaszcza z zakresu zarządzania przedsiębiorstwem, funkcjonuje wiele definicji przedsiębiorczości, zauważalna jest pewna ewolucja poglądów akcentujących różne aspekty przedsiębiorczości, na ogół odwołujących się tak zwanych kompetencji społecznych, zachowań przedsiębiorczych.

Między innymi J.A. Schumpeter (tradycyjnie kojarzony z pierwszymi ujęciami pojęcia przedsiębiorczości) traktował to pojęcie jako stan umysłu i postawę, sposób myślenia i działania. Zjawisko przedsiębiorczości postrzegane było $\mathrm{w}$ powiązaniu z działaniami przedsiębiorczymi w powiązaniu z przełomowymi innowacjami (Schumpeter, 1960, 104; Stańczyk, Stańczyk, 2017, 120).

Przedsiębiorczość można rozumieć więc jako pewną formę działania, cechę przedsiębiorcy i przedsiębiorstwa, którą rozumie się jako gotowość i zdolność do podejmowania i rozwiązywania w sposób twórczy i nowatorski nowych problemów, umiejętność wykorzystania pojawiających się szans i okazji oraz elastycznego przystosowywania się do zmieniających się warunków. Za podstawę takich działań można uznać innowacje (Drucker, 1992, 7; 2004, 161). Pozytywny wpływ

1 Termin „przedsiębiorczość” po raz pierwszy pojawił się na przełomie XVIII i XIX wieku między innymi w dziełach przedstawicieli ekonomicznej i społecznej myśli liberalnej. Za prekursorów uznaje się A. Smitha, J.B. Saya i J. Schumpetera - por. na przykład A. Potocki (2000, 20); w literaturze naukowej funkcjonuje również koncepcja, zgodnie z którą prekursorem pojęcia „przedsiębiorczość” (od francuskiego słowa entrepreneur 'przedsiębiorca') był francuski ekonomista R. Cantillon — por. T. Piecuch (2010, 15); Stańczyk, Stańczyk (2017, 119-121).

Ekonomia - Wroclaw Economic Review 26/, 2020

(C) for this edition by CNS 
innowacji na rozwój przedsiębiorstw podkreśla się też w wielu innych badaniach naukowych — por. na przykład Bhaskaran (2006), Medina, Morales (2013).

W wymiarze ekonomicznym na uwagę zasługuje nurt badań, w których definiuje się przedsiębiorczość w aspekcie rezultatów działalności, efektywności działań - między innymi w badaniach naukowych nawiązujących do koncepcji F. Knighta (1921), według którego ryzyko jest kategorią wpisaną w działalność przedsiębiorców, a przedsiębiorczość oznacza zysk osiągany w zamian za ponoszenie niepewności i ryzyka — czy nurt badań A.H. Cole’a (1959) utożsamiającego przedsiębiorczość z celową działalnością skierowaną na założenie i rozwój firmy nastawionej na zysk.

Również wspominany wcześniej J.A. Schumpeter (1934) podkreślał, że przedsiębiorczość to działalność, która polega na wprowadzeniu nowych kombinacji czynników produkcji oraz na tworzeniu nowych, bardziej efektywnych form organizacyjnych działalności gospodarczej (Gaweł, 2007, 234).

Zgodnie z koncepcją opracowaną pod kierunkiem J.W. Carlanda kluczowy czynnik wyróżniający prawdziwych przedsiębiorców wiąże się z podstawową motywacją - realizacją celów finansowych ściśle powiązanych z potrzebami własnej rodziny. Przedsiębiorca to natomiast osoba, która przy podejmowaniu decyzji kieruje się motywem wzrostu i zysków. Cechuje ją zachowanie innowacyjne i stosowanie strategicznych metod zarządzania (Carland et al., 1984, 358; 2001, 75).

W wielu współczesnych pracach naukowych na ogół przedsiębiorczość utożsamia się z umiejętnością dostrzegania nowych szans, poszukiwaniem okazji, skutecznością osiągania celów (w tym osiągnięcia zysku), maksymalizacją wyników finansowych (por. na przykład Skowronek-Mielczarek, 2003, 214; Strużycki, 2002, 109-113). Czyli w ujęciu syntetycznym przedsiębiorczość oznacza zdolność przełożenia szeroko rozumianej wiedzy, indywidualnych cech człowieka, zaczerpniętych wzorców społecznych na wymierne efekty gospodarcze lub społeczne (Chmieliński, 2006, 171).

Obecnie w wielu badaniach regionalnych przedsiębiorczość i konkurencyjność traktowana jest jako determinanta rozwoju społeczno-gospodarczego regionu (por. między innymi Bartosiewicz, Stańczyk, 2018, 9). Zadania i działania związane z zapewnieniem odpowiednich warunków rozwoju przedsiębiorczości wymienione są $\mathrm{w}$ większości współcześnie obowiązujących dokumentów strategicznych i programów operacyjnych na poziomie zarówno krajowym, jak i regionalnym. Kluczowym dokumentem państwa polskiego w obszarze średnio- i długofalowej polityki gospodarczej na poziomie krajowym jest Strategia na rzecz odpowiedzialnego rozwoju do roku 2020 (z perspektywą do 2030) przyjęta przez Radę Ministrów w lutym 2017 roku. Zagadnienia związane z rozwojem przedsiębiorczości zostały ujęte między innymi w obszarach strategicznych: reindustrializacja, rozwój innowacyjnych firm, małe i średnie przedsiębiorstwa, w ramach celu szczegółowego - trwały wzrost gospodarczy oparty coraz bardziej na wiedzy, danych i doskonałości organizacyjnej (Strategia, 2017). 
W dokumencie tym wskazano nowy model rozwoju regionalnego Polski, który znalazł odzwierciedlenie w Krajowej strategii rozwoju regionalnego 2030 (przyjętej przez Radę Ministrów we wrześniu 2019 roku) będącej podstawowym dokumentem strategicznym polityki regionalnej państwa. Głównym celem tej strategii jest efektywne wykorzystanie endogenicznych potencjałów terytoriów i ich specjalizacji do osiągnięcia zrównoważonego rozwoju kraju, między innymi poprzez realizację celów szczegółowych, na przykład przez wzmacnianie regionalnych przewag konkurencyjnych, w tym wspieranie przedsiębiorczości na szczeblu regionalnym i lokalnym (Krajowa strategia, 2019).

Próbę zharmonizowania cyklicznych badań statystycznych nad przedsiębiorczością w ujęciu międzynarodowym podjęło przed kilku laty OECD we współpracy z Eurostatem w ramach programu EIP - Entrepreneurship Indicators Programme (Program Wskaźników Przedsiębiorczości). EIP to jeden z kluczowych elementów demografii przedsiębiorstw, uruchomiony w celu wypracowania metod ciągłego i zharmonizowanego pomiaru wskaźników rozwoju przedsiębiorczości i czynników, które jej sprzyjają².

Zaproponowano wówczas trzy kategorie wskaźników opisujących uwarunkowania przedsiębiorczości:

— czynniki decydujące o rozwoju przedsiębiorczości bądź jej zastoju (na przykład dostępność kapitału, edukacja i szkolenia, nakłady na badania i rozwój, dostęp do finansowania);

- wyniki przedsiębiorczości (na przykład wskaźniki oparte na liczbie przedsiębiorstw nowo powstałych — „,narodziny” i zlikwidowanych — „śmierć”, wskaźniki przeżycia pierwszego okresu funkcjonowania oraz wskaźniki rozwoju);

- wpływ przedsiębiorczości na sytuację społeczno-gospodarczą (na przykład na tworzenie miejsc pracy, wzrost gospodarczy czy redukcję ubóstwa).

Stworzenie tego modelu i grup wskaźników dało podstawę gromadzenia porównywalnych danych empirycznych dla krajów europejskich. W Polsce Główny Urząd Statystyczny, wykorzystując doświadczenia programu EIP, na podstawie dostępnych danych statystycznych, opracował metodę analizy przedsiębiorczości i w 2011 roku do statystyki publicznej zostało wprowadzone nowe badanie w tym zakresie. Dane wynikowe z tych badań dostarczają jedynie podstawowych informacji charakteryzujących rozwój i warunki powstawania oraz stan aktywności w odniesieniu tylko do zbiorowości przedsiębiorstw, które funkcjonują na rynku co najwyżej 5 lat.

\section{Metodologia analizy}

W niniejszym opracowaniu analiza przedsiębiorczości w wąskim zakresie nawiązuje koncepcyjnie do ogólnej idei europejskiego badania uwarunkowań przedsię-

2 Por. pierwszą edycję publikacji GUS prezentującej wyniki badań na temat wskaźników przedsiębiorczości i typologii przedsiębiorstw w zależności od kierunku i tempa zmian wyników finansowych (Wybrane wskaźniki..., 2015, 9).

Ekonomia - Wroclaw Economic Review 26/, 2020

(C) for this edition by CNS 
biorczości w ramach wspomnianego już, opracowanego przez OECD i Eurostat, Programu Wskaźników Przedsiębiorczości (EIP - Entrepreneurship Indicators Programme), koncentrując się na rozszerzonych wymiarach w kontekście efektywności działań przedsiębiorczych.

Wobec braku danych empirycznych z jednorodnych badań w zakresie przedsiębiorczości na poziomie województw i jednocześnie mając na uwadze literaturę przedmiotu, podobnie jak w pracy Stańczyk, Stańczyk (2017), na potrzeby niniejszej pracy zaproponowano wskaźniki na podstawie danych z krajowego rejestru urzędowego podmiotów gospodarki narodowej REGON, świadczących o aktywności w zakresie podejmowania działalności gospodarczej. W tym aspekcie pomiar przedsiębiorczości wiąże się między innymi z liczbą przedsiębiorstw nowo powstałych - nowo zarejestrowanych (narodziny firmy) oraz wyrejestrowanych (na przykład upadających z powodu zbyt silnej konkurencji).

Kolejnym analizowanym wymiarem przedsiębiorczości była innowacyjność przedsiębiorstw. Szczególną uwagę zwrócono na zróżnicowanie w poziomie nakładów w działalność innowacyjną oraz w poziomie wskaźników odnośnie do udziału wprowadzonych (sprzedanych) innowacji na ogólną wartość sprzedaży, przyjmując, że wskaźniki te świadczą o skutkach ekonomicznych, gospodarczych efektach działalności innowacyjnej.

Na potrzeby niniejszej publikacji analizą objęto również grupę charakterystyk sukcesu i efektywności w kierowaniu przedsiębiorstwem. Podstawowymi wskaźnikami efektywności (sukcesu) były wskaźniki finansowe, które mają na celu ocenę sytuacji ekonomiczno-finansowej jednostek gospodarczych województwa (na przykład wskaźnik rentowności, przychody z całokształtu działalności, w szczególności przychody ze sprzedaży na eksport).

Wybrane trzy wymiary przedsiębiorczości scharakteryzowano uwzględniając cechy, których wartości liczbowe miały postać wskaźników, co umożliwiło porównanie województw zróżnicowanych między innymi w aspekcie liczby ludności czy liczby działających przedsiębiorstw.

Klasyczną miarą charakteryzującą empiryczny obszar zmienności badanej cechy, na przykład zróżnicowania przestrzennego w przekroju wojewódzkim, jest rozstęp, czyli różnica między wartością maksymalną cechy a minimalną, to jest dla danego roku t:

$$
\mathrm{R}^{\mathrm{t}}=\mathrm{x}_{\max }^{\mathrm{t}}-\mathrm{x}_{\min }^{\mathrm{t}}
$$

gdzie

$\mathrm{x}_{\max }^{\mathrm{t}}-\mathrm{x}_{\min ,}^{\mathrm{t}}$ oznaczają odpowiednio maksymalną, minimalną wartość wskaźnika w roku $t$.

Jako że rozstęp nie daje informacji o zróżnicowaniu poszczególnych wartości cechy w zbiorowości, skorzystano ze wskaźnika dyspersji uwzględniającego odchylenia wartości danego wskaźnika od średniej krajowej we wszystkich 
województwach, ważone liczbą ludności, ewentualnie liczbą przedsiębiorstw w województwach:

$$
D^{t}=100 \cdot \frac{1}{Y} \cdot \sum_{i=1}^{n}\left|y_{i}-Y\right| \cdot \frac{L_{i}}{L},
$$

gdzie: Y oznacza wartość wskaźnika per capita przeciętnie w kraju w roku $t, Y_{i}$ dla każdego i-tego województwa, $L$ - oznacza liczbę ludności w kraju, $L_{i}$ - dla każdego i-tego województwa.

Źródłem danych empirycznych w opracowaniu są wyniki badań GUS z lat 2004-2018. W sporadycznych sytuacjach braku danych za 2004 rok przyjęto wartość z 2005 roku, a za 2018 rok wartość z 2017 roku.

Ujęcie dynamiczne umożliwiło określenie poziomu zmian rozwoju przedsiębiorczości $\mathrm{w}$ województwach oraz zmian w poziomie dysproporcji między województwami. Wartości wskaźników były podstawą oceny pozycji danego województwa względem pozostałych województw.

\section{Podmioty gospodarki narodowej zarejestrowane w rejestrze REGON}

Aktywność w zakresie podejmowania działalności gospodarczej — założenie bądź prowadzenie własnego przedsiębiorstwa (i zatrudniania pracowników) - jest na ogół łączona z pojęciem przedsiębiorczości lokalnej. Dane z krajowego rejestru urzędowego podmiotów gospodarki narodowej REGON mogą świadczyć o poziomie aktywności mieszkańców w zakresie podejmowania działalności gospodarczej.

W końcu grudnia 2018 roku w rejestrze REGON zarejestrowanych było w Polsce 788,5 tys. podmiotów gospodarki narodowej (bez indywidualnych gospodarstw rolnych $\left.{ }^{3}\right)$. W porównaniu z 2004 rokiem liczba podmiotów ogółem zwiększyła się o 70,8 tys., czyli o $23,3 \%$.

Największą dynamiką przyrostu liczby podmiotów wpisanych do rejestru REGON wyróżniało się województwo mazowieckie - wzrost o 39,4\% (w tym okresie przybyło 230,9 tys. podmiotów gospodarczych). W najmniejszym stopniu wzrosła liczba podmiotów w województwie łódzkim — jedynie o 1,1\% (przybyło 2,8 jednostki).

W całym analizowanym okresie wśród województw utrzymuje się wysoka pozycja województwa mazowieckiego pod względem liczby podmiotów w rejestrze REGON (stanowiących od 16,4\% ogólnej liczby podmiotów w Polsce w 2004 roku do 18,7\% w 2018). Począwszy od 2010 roku, pod względem liczby podmiotów w przeliczeniu na 10 tys. mieszkańców mazowieckie corocznie rów-

${ }^{3}$ Do rejestru REGON wpisywane są podmioty gospodarki narodowej (zwane jednostkami prawnymi), czyli osoby prawne, jednostki organizacyjne niemające osobowości prawnej, osoby fizyczne prowadzące działalność gospodarczą oraz ich jednostki lokalne (zakłady, oddziały, filie).

Ekonomia - Wroclaw Economic Review 26/, 2020

(C) for this edition by CNS 
nież zajmowało 1. lokatę w kraju (w latach 2004-2009 zajmowało 2. lokatę, po województwie zachodniopomorskim $)^{4}$.

W końcu 2018 roku na 10 tys. mieszkańców w skali kraju przypadało przeciętnie 1136 jednostek prowadzących działalność gospodarczą (w końcu 2004 roku — 937 jednostek). W przekroju województw można zaobserwować wzrost rozpiętości między wartościami skrajnymi wskaźnika — między najniższymi wartościami notowanymi w województwach wschodnich (szczególnie w podkarpackim) a najwyższymi w mazowieckim i zachodniopomorskim.

Zgodnie z koncepcją europejskiego badania demografii przedsiębiorstw oprócz analizy zasobów jednostek prowadzących działalność gospodarczą zwrócono także uwagę na kształtowanie się strumienia napływu nowych jednostek („narodzin” firm) i strumienia odpływu jednostek — zamykania działalności gospodarczej (,śmierci” firm).

Biorąc pod uwagę strumień nowo zarejestrowanych jednostek (w relacji do liczby ludności) w kolejnych latach po akcesji Polski do UE, można wyróżnić okres 2004-2010 (a zwłaszcza do 2008 roku), w którym wartości wskaźnika charakteryzuje wyraźna tendencja wzrostowa (z poziomu 61 nowych jednostek do 105 nowych jednostek na 10 tys. mieszkańców, czyli przeszło półtorakrotny wzrost). Natomiast w kolejnych latach widoczne jest niewielkie zmniejszenie skłonności do zakładania własnej działalności gospodarczej. Odnotowano już, z pewnymi wahaniami, małą tendencję spadkową natężenia rejestracji jednostek — do poziomu 91 nowo zarejestrowanych jednostek na 10 tys. mieszkańców w 2016 roku. W ostatnich dwóch latach objętych niniejszą analizą odnotowano wzrost rejestracji nowych podmiotów w rejestrze REGON do wielkości 392,7 tys. nowych podmiotów gospodarczych w 2018 roku, czyli do wielkości 102 nowych jednostek w przeliczeniu na 10 tys. mieszkańców (stanowiącej o 41 jednostek większą sumę niż w 2004 roku).

Pod względem natężenia strumienia „narodzin” firm (skłonności do zakładania własnej działalności gospodarczej), począwszy od 2010 roku, województwo mazowieckie plasowało się w pierwszym miejscu wśród województw (w latach 2004-2009 pierwsze lokaty zajmowało województwo zachodniopomorskie).

W przypadku strumienia wykreśleń z rejestru REGON do 2011 roku utrzymywała się niewielka tendencja wzrostowa, jakkolwiek nadal liczba jednostek wyrejestrowanych (liczby osób, które finalnie zdecydowały się zrezygnować z prowadzenia własnej firmy) była niższa od liczby jednostek nowo zarejestrowanych (liczby kandydatów na przedsiębiorców) i bilans rejestracji był dodatni. Stan liczebny zasobu funkcjonujących na rynku podmiotów gospodarczych się

${ }^{4}$ Na występujące w okresie od 2009 do 2011 roku, zarówno w skali kraju, jak i w poszczególnych województwach, wahania wartości zaproponowanych wskaźników (na przykład w przeliczeniu na 10 tys. liczby podmiotów gospodarczych w rejestrze REGON, w tym nowo zarejestrowanych) wpływ miały wprowadzane systemowe zmiany w sposobie rejestracji i aktualizacji rejestru REGON. 
zwiększał. Jedynie w 2011 roku liczba jednostek wyrejestrowanych była wyższa od liczby jednostek nowo zarejestrowanych (zarówno w kraju, jak i we wszystkich województwach, poza wielkopolskim i małopolskim).

Tabela 1. Podmioty gospodarki narodowej wpisane do rejestru REGON w przeliczeniu na 10 mieszkańców

\begin{tabular}{|c|c|c|c|c|}
\hline Wyszczególnienie & 2004 & 2008 & 2012 & 2018 \\
\hline $\begin{array}{l}\mathrm{X}_{\mathrm{O}} \text { podmioty ogółem } \\
\text { (stan w dniu } 31 \mathrm{XII} \text { ) }\end{array}$ & 937 & 986 & 1032 & 1136 \\
\hline MAX w województwach & $\begin{array}{r}1191 \\
\text { zachodnio- } \\
\text { pomorskie }\end{array}$ & $\begin{array}{r}1259 \\
\text { zachodnio- } \\
\text { pomorskie }\end{array}$ & $\begin{array}{r}1321 \\
\text { mazowieckie }\end{array}$ & $\begin{array}{r}1514 \\
\text { mazowieckie }\end{array}$ \\
\hline MIN w województwach & $\begin{array}{r}665 \\
\text { podkarpackie }\end{array}$ & $\begin{array}{r}688 \\
\text { podkarpackie }\end{array}$ & $\begin{array}{r}728 \\
\text { podkarpackie }\end{array}$ & $\begin{array}{r}821 \\
\text { podkarpackie }\end{array}$ \\
\hline MAX-MIN rozstęp $(\mathrm{R})$ & 526 & 571 & 593 & 693 \\
\hline Dyspersja (D) & 12,5 & 14,3 & 14,6 & 16,1 \\
\hline $\begin{array}{l}\mathrm{XN} \text { podmioty nowo } \\
\text { zarejestrowane (w ciągu } \\
\text { roku) }\end{array}$ & 61 & 83 & 93 & 102 \\
\hline MAX w województwach & $\begin{array}{r}81 \\
\text { zachodnio- } \\
\text { pomorskie }\end{array}$ & $\begin{array}{r}111 \\
\text { zachodniopo- } \\
\text { morskie }\end{array}$ & $\begin{array}{r}115 \\
\text { mazowieckie }\end{array}$ & $\begin{array}{r}135 \\
\text { mazowieckie }\end{array}$ \\
\hline MIN w województwach & $\begin{array}{r}42 \\
\text { podkarpackie }\end{array}$ & $\begin{array}{r}56 \\
\text { podkarpackie }\end{array}$ & $\begin{array}{r}66 \\
\text { podkarpackie }\end{array}$ & $\begin{array}{r}73 \\
\text { opolskie }\end{array}$ \\
\hline MAX-MIN Rozstęp (R) & 39 & 55 & 49 & 62 \\
\hline dyspersja (D) & 14,6 & 16,0 & 15,3 & 17,1 \\
\hline $\begin{array}{l}100 * \mathrm{X}_{\mathrm{N}} / \mathrm{X}_{\mathrm{W}} \text { iloraz } \\
\text { podmiotów nowo } \\
\text { zarejestrowanych } \\
\text { i wyrejestrowanych }\end{array}$ & 120 & 130 & 142 & 118 \\
\hline MAX w województwach & $\begin{array}{r}174 \\
\text { mazowieckie }\end{array}$ & $\begin{array}{r}174 \\
\text { mazowieckie }\end{array}$ & $\begin{array}{r}160 \\
\text { mazowieckie }\end{array}$ & $\begin{array}{r}147 \\
\text { małopolskie }\end{array}$ \\
\hline MIN w województwach & $\begin{array}{r}62 \\
\text { podlaskie }\end{array}$ & $\begin{array}{r}70 \\
\text { lubuskie }\end{array}$ & $\begin{array}{r}117 \\
\text { zachodniopo- } \\
\text { morskie }\end{array}$ & $\begin{array}{r}106 \\
\text { lubuskie }\end{array}$ \\
\hline MAX-MIN rozstęp (R) & 112 & 104 & 43 & 41 \\
\hline dyspersja (D) & 21,3 & 13,0 & 6,4 & 9,1 \\
\hline
\end{tabular}

Źródło: opracowanie własne na podstawie danych GUS.

Ekonomia - Wroclaw Economic Review 26/, 2020

(C) for this edition by CNS 
W analizie monitoringu lokalnej przedsiębiorczości szczególne znaczenie może mieć wskaźnik wyrażający relację podmiotów nowo zarejestrowanych (,narodziny" firmy) do podmiotów wyrejestrowanych (,śmierć” firmy) w postaci ilorazu: XN/XW. Wskaźnik ten nazywany się wskaźnikiem rotacji finalnej, gdyż w pewnym sensie ilustruje tendencje dotyczące decyzji o wyborze ścieżki przedsiębiorczej bądź całkowitej rezygnacji z tej ścieżki (por. Cieślik, 2014, 93; Cieślik (red.) 2014, 18).

$\mathrm{W}$ każdym roku w analizowanym przedziale czasowym (poza 2011 rokiem) iloraz $\mathrm{X}_{\mathrm{N}} / \mathrm{X}_{\mathrm{W}}$ dawał wynik powyżej 1, czyli rotacja finalna pozytywnie wpływała na poziom aktywności przedsiębiorczej. Najwyższa wartość wskaźnika rotacji finalnej wystąpiła w 2010 roku, w którym średnio na 100 jednostek wykreślonych z rejestru przypadało 169 nowo zarejestrowanych (w 2011 roku 90 nowo zarejestrowanych). Po 2011 roku we wszystkich województwach wskaźnik ten przyjmował wartości powyżej 1 .

Jako uzupełnienie przedstawionej analizy warto przytoczyć wyniki prowadzonych w ostatnich latach przez GUS badań na temat przeżywalności przedsiębiorstw. Na podstawie informacji pozyskanych od przedsiębiorstw w badaniach tych stwierdzono, że najwięcej przedsiębiorstw upada w pierwszym roku prowadzenia działalności. Spośród ogólnej liczby powstałych w 2017 roku nowych przedsiębiorstw $66,3 \%$ było dalej aktywnych do 2018 roku, to jest po roku działalności (wobec wskaźnika przeżywalności po roku działalności dla podmiotów powstałych w 2016 roku na poziomie $69,9 \%$ ). W układzie przestrzennym największy wskaźnik przeżywalności dla podmiotów powstałych w 2017 roku miał miejsce w województwie podlaskim $(88,4 \%)$ oraz w opolskim i świętokrzyskim (po 76,7\%), natomiast najmniejszy w łódzkim i zachodniopomorskim (odpowiednio $57,6 \%$ i $59,9 \%)^{5}$.

\section{Innowacyjność przedsiębiorstw}

O aktywności przedsiębiorców w zakresie działań innowacyjnych mogą świadczyć poniesione przez te firmy nakłady finansowe na działalność innowacyjną w danym roku sprawozdawczym, które obejmowały tak zwany budżet innowacji, czyli wszelkie wydatki na innowacje - bieżące i inwestycyjne, poniesione na prace zarówno zakończone sukcesem (czyli zakończone wdrożeniem innowacji), jak i niezakończone sukcesem — kontynuowane, przerwane lub zaniechane przed ukończeniem ${ }^{6}$.

5 Na podstawie publikacji Przedsiębiorstwa niefinansowe..., 2019.

${ }^{6}$ Por. między innymi formularz sprawozdania PNT02 i PNT02/u o działalności innowacyjnej przedsiębiorstw w 2015 roku, s. 4. GUS. Data dostępu: 13.07.2020, http://form.stat.gov.pl/formularze/2016/index.htm. 
W sektorze przemysłowym nakłady na innowacje osiągnęły w 2018 roku w Polsce wartość 23,4 mld zł — o 16,5\% mniej niż odnotowana wielkość sprzed roku, natomiast o $63,2 \%$ więcej niż w 2005 roku. Warto podkreślić, że w strukturze nakładów na działalność innowacyjną według źródeł finansowania niezmiennie największy był udział środków własnych przedsiębiorców (obejmowały one 75,5\% ogółu nakładów w 2018 roku); znacznie mniejszy udział miały kredyty, pożyczki i inne zobowiązania finansowe od instytucji finansowych $(8,1 \%)$ czy środki pozyskane z zagranicy $(5,4 \%)$.

W przekroju województw największym budżetem na innowacje w przemyśle dysponowało województwo mazowieckie — o wartości 3,9 mln zł w 2018 roku (stanowiącym 16,8\% krajowego budżetu na innowacje), a najmniejszym podlaskie - 0,2 mld zł ( $1 \%$ krajowego budżetu).

Łącznie w kraju 55,9\% ogólnej wielkości nakładów na innowacje pochodziło z czterech województw (mazowieckiego, łódzkiego, śląskiego i małopolskiego), podczas gdy łączny budżet na innowacje pochodzący z województw podlaskiego, świętokrzyskiego, warmińsko-mazurskiego i lubuskiego to tylko 5,5\%.

W 2018 roku nakłady finansowe na działalność innowacyjną poniosło 15,7\% przedsiębiorstw przemysłowych. W pierwszych latach badanego okresu wystąpiła z pewnymi wahaniami tendencja spadkowa tego wskaźnika - do poziomu 12,8\% w 2011 roku (najniższego w całym okresie). Natomiast po 2011 roku notuje się systematyczną tendencję wzrostową.

W grupie przedsiębiorstw przemysłowych pod względem odsetka jednostek, które odnotowały nakłady na działalność innowacyjną, w ostatnich latach miejsca pierwsze w rankingu województw zajmowały: podkarpackie, opolskie oraz mazowieckie. W województwach tych w okresie 2011-2018 w największym stopniu nastąpił wzrost odsetka przedsiębiorstw inwestujących w innowacje. Konsekwencją nierównomiernej dynamiki analizowanego odsetka przedsiębiorstw w układzie województw jest wzrost dysproporcji między województwami (por. tabela 2).

Tabela 2. Aktywność innowacyjna przedsiębiorstw przemysłowych

\begin{tabular}{|c|c|c|c|c|}
\hline Wyszczególnienie & 2005 & 2008 & 2012 & 2018 \\
\hline $\begin{array}{l}\text { udział przedsiębiorstw } \\
\text { przemysłowych, które } \\
\text { poniosły nakłady na } \\
\text { działalność innowacyjną } \\
\text { w ogólnej liczbie } \\
\text { przedsiębiorstw (w \%) }\end{array}$ & 38,9 & 17,1 & 12,9 & 15,7 \\
\hline MAX w województwach & $\begin{array}{r}49,2 \\
\text { śląskie }\end{array}$ & $\begin{array}{r}19,8 \\
\text { mazowieckie }\end{array}$ & $\begin{array}{r}19,3 \\
\text { podlaskie }\end{array}$ & $\begin{array}{r}23,8 \\
\text { podlaskie }\end{array}$ \\
\hline MIN w województwach & $\begin{array}{r}25,2 \\
\text { zachodnio- } \\
\text { pomorskie }\end{array}$ & $\begin{array}{r}9,8 \\
\text { lubuskie }\end{array}$ & $\begin{array}{r}9,6 \\
\text { wielkopolskie }\end{array}$ & $\begin{array}{r}8,9 \\
\text { zachodnio- } \\
\text { pomorskie }\end{array}$ \\
\hline
\end{tabular}

Ekonomia - Wroclaw Economic Review 26/, 2020

(C) for this edition by CNS 


\begin{tabular}{|c|c|c|c|c|}
\hline MAX-MIN Rozstęp (R) & 24,0 & 10,0 & 9,6 & 14,9 \\
\hline dyspersja (D) & 14,7 & 13,0 & 14,5 & 15,7 \\
\hline $\begin{array}{l}\text { nakłady na działalność } \\
\text { innowacyjną } \\
\text { w przedsiębiorstwach } \\
\text { przemysłowych na } \\
1 \text { mieszkańca (w PLN) }\end{array}$ & 375,5 & 647,6 & 558,9 & 608,9 \\
\hline MAX w województwach & $\begin{array}{r}686,2 \\
\text { mazowieckie }\end{array}$ & $\begin{array}{r}1021,0 \\
\text { pomorskie }\end{array}$ & $\begin{array}{r}943,6 \\
\text { mazowieckie }\end{array}$ & $\begin{array}{l}1421,7 \\
\text { tódzkie }\end{array}$ \\
\hline MIN w województwach & $\begin{array}{r}120,1 \\
\text { lubuskie }\end{array}$ & $\begin{array}{r}217,7 \\
\text { warmińsko- } \\
\text {-mazurskie }\end{array}$ & $\begin{array}{r}159,9 \\
\text { opolskie }\end{array}$ & $\begin{array}{r}200,9 \\
\text { podlaskie }\end{array}$ \\
\hline MAX-MIN Rozstęp (R) & 566,1 & 803,3 & 783,7 & 1220,8 \\
\hline dyspersja (D) & 36,1 & 41,4 & 34,0 & 36,3 \\
\hline $\begin{array}{l}\text { udział przedsiębiorstw } \\
\text { innowacyjnych } \\
\text { w ogólnej liczbie } \\
\text { przedsiębiorstw } \\
\text { przemysłowych (w \%) }\end{array}$ & 42,0 & 21,4 & 16,5 & 24,0 \\
\hline MAX w województwach & $\begin{array}{r}51,2 \\
\text { śląskie }\end{array}$ & $\begin{array}{r}25,8 \\
\text { mazowieckie }\end{array}$ & $\begin{array}{r}22,3 \\
\text { opolskie }\end{array}$ & $\begin{array}{r}30,7 \\
\text { lubelskie }\end{array}$ \\
\hline MIN w województwach & $\begin{array}{r}29,7 \\
\text { zachodnio- } \\
\text { pomorskie }\end{array}$ & $\begin{array}{r}14,7 \\
\text { lubuskie }\end{array}$ & $\begin{array}{r}11,0 \\
\text { pomorskie }\end{array}$ & $\begin{array}{r}19,3 \\
\text { świętokrzyskie }\end{array}$ \\
\hline MAX-MIN rozstęp (R) & 21,4 & 11,2 & 11,3 & 11,4 \\
\hline dyspersja (D) & 12,8 & 13,6 & 15,8 & 10,8 \\
\hline $\begin{array}{l}\text { udział przychodów netto } \\
\text { ze sprzedaży produktów } \\
\text { innowacyjnych } \\
\text { w przychodach netto ze } \\
\text { sprzedaży ogółem (w \%) }\end{array}$ & $13,5^{*}$ & 12,4 & 9,2 & 9,1 \\
\hline MAX w województwach & $\begin{array}{r}25,8^{*} \\
\text { pomorskie }\end{array}$ & $\begin{array}{r}28,0 \\
\text { pomorskie }\end{array}$ & $\begin{array}{r}36,3 \\
\text { pomorskie }\end{array}$ & $\begin{array}{r}12,8 \\
\text { lubuskie }\end{array}$ \\
\hline MIN w województwach & $\begin{array}{r}4,3^{*} \\
\text { podlaskie }\end{array}$ & $\begin{array}{r}6,2 \\
\text { lubuskie }\end{array}$ & $\begin{array}{r}3,1 \\
\text { warmińsko- } \\
\text {-mazurskie }\end{array}$ & $\begin{array}{r}3,2 \\
\text { zachodniopo- } \\
\text { morskie }\end{array}$ \\
\hline MAX-MIN rozstęp (R) & 21,4 & 21,8 & 33,2 & 9,6 \\
\hline dyspersja (D) & 37,9 & 24,4 & 47,8 & 15,6 \\
\hline
\end{tabular}

*dotyczy 2006 roku

Źródło: opracowanie własne na podstawie danych GUS.

Ekonomia - Wroclaw Economic Review 26/, 2020

(C) for this edition by CNS 
O prorozwojowym nastawieniu przedsiębiorstw w regionie może świadczyć wartość nakładów na innowacje w przeliczeniu na 1000 mieszkańców. W skali całego kraju otrzymano w analizowanym przedziale czasowym wielkości na poziomie od 375 tys. zł w 2005 roku do 609 tys. zł w 2018 roku. Najwyższą wielkość nakładów na innowacje w relacji do liczby ludności odnotowano w 2015 roku -809 tys. zł. Po 2015 roku wartość tego wskaźnika stopniowo się zmniejszała - o 23,9\%.

W 2018 roku w porównaniu do 2015 roku w przekroju województw zaobserwowano zwiększenie dysproporcji między skrajnymi wartościami przeciętnych nakładów na innowacje, które wynikało również z wysokiej dynamiki wzrostu w głównych województwach (przede wszystkim w mazowieckim i łódzkim) oraz niewielkich zmian, a nawet zmniejszenia wartości tego wskaźnika w jednostkach zajmujących odległe miejsca w rankingu województw (między innymi w lubuskim).

Z punktu widzenia działalności gospodarczej, w tym innowacyjnej, ważna jest efektywność działalności w kontekście korzyści dla gospodarki, czyli zdolność przedsiębiorstw do przenoszenia poniesionych nakładów na wymierne efekty. W artykule szczególnie zwrócono uwagę na innowatorów - autorów innowacji, przedsiębiorstwa, którym udało się z sukcesem doprowadzić do wdrożenia i zastosowania w praktyce innowacji. O skutkach ekonomicznych, gospodarczych efektach działalności innowacyjnej świadczy udział wprowadzonych (sprzedanych) innowacji na ogólną wartość sprzedaży.

W świetle wyników badań GUS w 2018 roku odsetek innowatorów w sektorze przemysłowym, to jest przedsiębiorstw, które w okresie trzyletnim 2016-2018 wdrożyły przynajmniej jedną innowację techniczną (nowy lub ulepszony produkt bądź nowy lub ulepszony proces biznesowy) kształtował się na poziomie $24,0 \%$. Biorąc pod uwagę okres 2011-2018, stwierdzono w skali kraju niewielki wzrost udziału przedsiębiorstw innowacyjnych $\mathrm{w}$ przemyśle, podczas gdy w latach wcześniejszych — spadek do najniższego poziomu 16,1\% w 2011 roku. Najwyższymi odsetkami przedsiębiorstw, które w 2018 roku odnotowały wdrożenie przynajmniej jednej innowacji, wyróżniały się województwa: lubelskie, podkarpackie i mazowieckie, a najniższymi — świętokrzyskie, warmińsko-mazurskie i łódzkie. W ciągu całego analizowanego okresu po akcesji Polski do Unii Europejskiej lokaty województw się zmieniały, przy czym w najmniejszym stopniu w przypadku województwa podkarpackiego, plasującego się na ogół na pierwszych lokatach, oraz województwa łódzkiego, plasującego się na ogół na ostatnich lokatach.

Ważną informacją o wpływie innowacji produktowych na ogólną strukturę przychodów i poziom innowacyjności przedsiębiorstwa jest udział przychodów w badanym roku ze sprzedaży produktów nowych lub istotnie ulepszonych, wprowadzonych na rynek w ciągu ostatnich trzech lat, w wartości przychodów ze sprzedaży ogółem. W wypadku sektora przemysłowego udział przychodów netto ze sprzedaży produktów innowacyjnych wprowadzonych na rynek w latach 2016-2018 w przychodach netto ze sprzedaży w 2018 roku wyniósł 9,1\% ogólnej 
wartości przychodów netto (wobec niższej wielkości — 7,1\% w 2017 roku oraz wyższej 13,5\% w $2006 \mathrm{roku}$ ). W ostatnim pięcioleciu w porównaniu do pierwszego pięciolecia analizowanego przedziału czasowego innowacje produktowe miały mniejszy wpływ na ogólną strukturę przychodów i poziom innowacyjności przedsiębiorstwa - zmniejszyła się efektywność działań innowacyjnych. Najwyższymi udziałami przychodów ze sprzedaży innowacji wyróżniało się w każdym roku (poza latami 2016 i 2018) województwo pomorskie. W 2018 roku wyższą wartość tego udziału osiągnęli przedsiębiorcy z województwa lubuskiego $(12,8 \%)$ przy najniższej wartości w przypadku zachodniopomorskiego (3,2\%).

\section{Wyniki finansowe podmiotów gospodarczych}

Na podstawie wyników sprawozdawczości GUS w 2018 roku objęte niniejszą analizą przedsiębiorstwa o liczbie pracujących 10 i więcej osób uzyskały lepsze wyniki finansowe niż w latach wcześniejszych.

Przychody z całokształtu działalności przedsiębiorstw w Polsce charakteryzuje bardzo duży stopień koncentracji przestrzennej (większy niż w przypadku analizowanych wcześniej nakładów na działalność innowacyjną). W kraju w 2018 roku 57,8\% ogólnej wielkości przychodów pochodziło z przedsiębiorstw zlokalizowanych w trzech województwach (mazowieckim, śląskim i wielkopolskim, w tym $33,2 \% \mathrm{w}$ województwie mazowieckim). Trzy województwa o najniższych przychodach przedsiębiorstw: podlaskie, warmińsko-mazurskie i świętokrzyskie łącznie skupiały przychody z całokształtu działalności stanowiące 4,3\% ogólnej wielkości w kraju. W latach 2005-2018, zarówno w skali kraju, jak i w poszczególnych województwach, stwierdzono wysoką dynamikę wielkości przychodów z działalności przedsiębiorstw (blisko dwuipółkrotny wzrost przeciętnie w kraju). Przy tym zdecydowanie szybszy wzrost przychodów wystąpił w pierwszym podokresie, szczególnie do 2008 roku — wzrost o 45,0\%, niż w ostatnim - wzrost o 21,3\% w latach 2015-2018 (wobec wzrostu tylko o 6,5\% w 2011-2014).

Rozpatrując w układzie międzywojewódzkim wielkość przychodów z całokształtu działalności przedsiębiorstw w relacji do liczby mieszkańców, stwierdzono, że najwyższe wartości tego wskaźnika występowały niezmiennie w przedsiębiorstwach zlokalizowanych w województwie mazowieckim — od 90,9 tys. zł na 1 mieszkańca w 2005 roku do 188 tys. zł w 2018 roku (czyli ponaddwukrotnie więcej niż przeciętna krajowa) ${ }^{7}$. Oprócz województwa mazowieckiego

${ }^{7}$ Warto dodać, że w świetle przeprowadzonych w ostatnich latach badań GUS na temat wskaźników przedsiębiorczości w układzie jednostek, realizowanych zgodnie z metodologią międzynarodową (wypracowaną w ramach EIP - Entrepreneurship Indicators Programme), województwo mazowieckie wyróżniało się najwyższymi odsetkami tak zwanych przedsiębiorstw wzrostowych, czyli takich, w których łączne tempo wzrostu przychodów w trzyletnim okresie działalności wyno-

Ekonomia - Wroclaw Economic Review 26/, 2020

(C) for this edition by CNS 
jedynie w województwie wielkopolskim niezmiennie w całym badanym okresie przychody z całokształtu działalności w przeliczeniu na 1 mieszkańca przekraczały przeciętną krajową wielkość. Ostatnie pozycje w rankingu województw pod względem tego wskaźnika zajmowało województwo lubelskie, w którym w 2018 roku wskaźnik ten wynosił 28,2 tys. zł, czyli 35,4\% przeciętnej krajowej (15\% poziomu województwa mazowieckiego). Zróżnicowanie województw w ciągu badanego przedziału czasowego nie zmieniło się znacznie (por. wartości wskaźnika dyspersji w tabeli 3).

Zjawisko przedsiębiorczości można analizować także poprzez wskaźnik prezentujący średnią wartość wyniku finansowego brutto (obliczaną jako różnicę przychodów ogółem i kosztów ogółem) w przeliczeniu na 1 przedsiębiorstwo. W każdym z województw przychody z całokształtu działalności podmiotów przewyższały poniesione koszty, dlatego ogółem wynik z działalności gospodarczej (wynik finansowy brutto) utrzymywał się na dodatnim poziomie. Przeciętnie w Polsce w 2018 roku na 1 przedsiębiorstwo o liczbie pracujących 10 i więcej osób przypadał wynik finansowy brutto o wartości 7776 tys. zł (wobec 8407 tys. w 2017 roku oraz 4168 tys. zł w 2005 roku). Najwyższą wartość tego wskaźnika niezmiennie w każdym roku badanego przedziału czasowego wypracowały przedsiębiorstwa $\mathrm{z}$ województwa mazowieckiego — średnio na przedsiębiorstwo od 10259 tys. zł w 2005 roku do 14065 tys. zł w 2018 roku (co stanowiło odpowiednio 246\% i 181\% przeciętnej krajowej). Wysokie wartości średniego wyniku finansowego notowano również w województwach wielkopolskim i pomorskim oraz dolnośląskim, łódzkim i małopolskim. Natomiast najniższe wartości najczęściej osiągały przedsiębiorstwa mające siedzibę w województwach warmińsko-mazurskim, podlaskim oraz zachodniopomorskim w 2018 roku średni wynik finansowy przedsiębiorstw stanowił odpowiednio 44\%, 47\% i 51\% przeciętnej krajowej (wobec nieznacznie mniejszych udziałów w 2005 roku - odpowiednio 39\%, 45\% i 34\% przeciętnej krajowej).

Celem określenia, jaki procent zysku w przedsiębiorstwach przynosi dana wartość sprzedaży, jak korzystnie dolnośląskie przedsiębiorstwa na tle innych województw produkują i sprzedają swoje produkty, użyto wskaźnika rentowności obrotu brutto (wskaźnika stopy zysku). Ilustruje on relację wyniku finansowego brutto (zysku lub straty) do przychodów z całokształtu działalności.

Analizując dane w ujęciu czasowym, można stwierdzić, zarówno w skali kraju, jak i na poziomie województw, że w ostatnim podokresie systematyczne zmniejszały się wartości wskaźnika rentowności ze sprzedaży produktów, towarów i materiałów, który w 2018 roku osiągnął poziom 3,7\% (wobec $4,4 \% \mathrm{w}$ roku poprzednim). Natomiast nieznacznie większe wartości wystąpiły w pierwszym podokresie — do 2007 roku, w którym rentowność obrotu brut-

siło $72,8 \%$ i więcej (co oznacza średnioroczny wzrost przychodów o $20 \%$ i więcej) — por. załącznik tabelaryczny do publikacji Wybrane wskaźniki..., 2019. 
to była na poziomie $6,1 \%$ - najwyższym w całym analizowanym przedziale czasowym. W pierwszych latach członkostwa w UE, w latach przed światowym kryzysem, mniejsza wartość sprzedaży mogła zatem być zrealizowana, aby osiągnąć określoną kwotę zysku — wyższa była efektywność poniesionych nakładów i osiągniętych przychodów. Wraz z ogólną tendencją niewielkiego zmniejszenia się rentowności w przedsiębiorstwach nastąpiło zmniejszenie dysproporcji międzywojewódzkich.

Tabela 3. Wybrane wyniki finansowe podmiotów gospodarczych

\begin{tabular}{|c|c|c|c|c|}
\hline Wyszczególnienie & 2005 & 2008 & 2012 & 2018 \\
\hline $\begin{array}{l}\text { przychody z całokształtu } \\
\text { działalności na } \\
1 \text { mieszkańca (w PLN) }\end{array}$ & 34449 & 49999 & 61848 & 79583 \\
\hline MAX w województwach & $\begin{array}{r}90887 \\
\text { mazowieckie }\end{array}$ & $\begin{array}{r}129280 \\
\text { mazowieckie }\end{array}$ & $\begin{array}{r}155668 \\
\text { mazowieckie }\end{array}$ & $\begin{array}{r}188006 \\
\text { mazowieckie }\end{array}$ \\
\hline MIN w województwach & $\begin{array}{r}12481 \\
\text { lubelskie }\end{array}$ & $\begin{array}{r}19207 \\
\text { warmińsko- } \\
\text {-mazurskie }\end{array}$ & $\begin{array}{r}21679 \\
\text { warmińsko- } \\
\text {-mazurskie }\end{array}$ & $\begin{array}{r}28174 \\
\text { lubelskie }\end{array}$ \\
\hline MAX-MIN Rozstęp (R) & 78406 & 110073 & 133989 & 159831 \\
\hline dyspersja (D) & 33,4 & 32,3 & 34,2 & 33,5 \\
\hline $\begin{array}{l}\text { wynik finansowy brutto na } \\
1 \text { przedsiębiorstwo } \\
\text { (w tys. PLN) }\end{array}$ & 4168 & 4560 & 5648 & 7776 \\
\hline MAX w województwach & $\begin{array}{r}10259 \\
\text { mazowieckie }\end{array}$ & $\begin{array}{r}8793 \\
\text { mazowieckie }\end{array}$ & $\begin{array}{r}9883 \\
\text { mazowieckie }\end{array}$ & $\begin{array}{r}14065 \\
\text { mazowieckie }\end{array}$ \\
\hline MIN w województwach & $\begin{array}{r}1418 \\
\text { zachodnio- } \\
\text { pomorskie }\end{array}$ & $\begin{array}{r}975 \\
\text { zachodnio- } \\
\text { pomorskie }\end{array}$ & $\begin{array}{r}1483 \\
\text { podlaskie }\end{array}$ & $\begin{array}{r}3412 \\
\text { warmińsko- } \\
\text {-mazurskie }\end{array}$ \\
\hline MAX-MIN Rozstęp (R) & 8841 & 7818 & 8400 & 10653 \\
\hline dyspersja (D) & 48,8 & 31,8 & 29,5 & 25,3 \\
\hline $\begin{array}{l}\text { wskaźnik rentowności obro- } \\
\text { tu brutto }(\mathrm{w} \%)\end{array}$ & 4,9 & 4,2 & 4,2 & 3,7 \\
\hline MAX w województwach & $\begin{array}{r}7,9 \\
\text { opolskie }\end{array}$ & $\begin{array}{r}10,6 \\
\text { opolskie }\end{array}$ & $\begin{array}{r}6,7 \\
\text { dolnośląskie }\end{array}$ & $\begin{array}{r}4,7 \\
\text { kujawsko- } \\
\text {-pomorskie }\end{array}$ \\
\hline MIN w województwach & $\begin{array}{r}3,0 \\
\text { zachodnio- } \\
\text { pomorskie }\end{array}$ & $\begin{array}{r}1,7 \\
\text { zachodnio- } \\
\text { pomorskie }\end{array}$ & $\begin{array}{r}1,8 \\
\text { podlaskie }\end{array}$ & $\begin{array}{r}2,9 \\
\text { podlaskie }\end{array}$ \\
\hline MAX-MIN rozstęp $(\mathrm{R})$ & 4,9 & 8,9 & 4,9 & 1,8 \\
\hline
\end{tabular}




\begin{tabular}{|l|r|r|r|r|}
\hline dyspersja (D) & 15,4 & 22,6 & 16,3 & 14,0 \\
\hline $\begin{array}{l}\text { wartość eksportu } \\
\text { dokonanego przez podmioty } \\
\text { z udziałem kapitału } \\
\begin{array}{l}\text { zagranicznego } \\
\text { na 1 mieszkańca (w PLN) }\end{array}\end{array}$ & 4660 & 6586 & 9307 & 13400 \\
\hline MAX w województwach & $\begin{array}{r}8308 \\
\text { mazowieckie }\end{array}$ & $\begin{array}{r}11260 \\
\text { mazowieckie }\end{array}$ & $\begin{array}{r}15814 \\
\text { dolnośląskie }\end{array}$ & $\begin{array}{r}21139 \\
\text { mazowieckie }\end{array}$ \\
\hline MIN w województwach & 844 & $\begin{array}{r}922 \\
1827\end{array}$ & $\begin{array}{r}2394 \\
\text { lubelskie }\end{array}$ & $\begin{array}{r}1 \text { lubelskie } \\
\text { lubelskie }\end{array}$ \\
\hline MAX-MIN Rozstęp (R) & 7464 & 10338 & 13987 & 18745 \\
\hline dyspersja (D) & 44,5 & 45,1 & 40,9 & 39,4 \\
\hline
\end{tabular}

Źródło: opracowanie własne na podstawie danych GUS.

Szczególną rolę w rozwoju przedsiębiorczości i budowie pozycji konkurencyjnej przedsiębiorstw odgrywa ekspansja zagraniczna poprzez wzmocnienie obecności na dotychczasowych rynkach i wchodzenie na nowe, w szczególności szybko rozwijające się rynki. O poziomie ekspansji zagranicznej mogą świadczyć wyniki działalności eksportowej.

Wartość przychodów ze sprzedaży na eksport wygenerowanych przez podmioty z udziałem kapitału zagranicznego, o liczbie pracujących 10 i więcej osób, osiągnęła w 2017 roku w skali Polski poziom 514,9 mld zł (wobec 177,8 mld zł w 2005 roku), przy czym przeszło 50\% krajowego eksportu pochodziło z przedsiębiorstw mających siedzibę w trzech województwach: mazowieckim, śląskim i wielkopolskim. Zarówno w skali kraju, jak i w każdym z województw w relacji do liczby mieszkańców wystąpił dynamiczny wzrost wartości eksportu. Przeciętnie w kraju wartość tych przychodów w przeliczeniu na 1 mieszkańca wzrosła w okresie 2005-2017 ponaddwuipółkrotnie, podczas gdy w województwach opolskim, łódzkim i małopolskim — ponadczterokrotnie (przy najsłabszej dynamice w warmińsko-mazurskim - wzrost tylko o 81\%). Największe wartości eksportu w relacji do liczby mieszkańców uzyskiwały podmioty zlokalizowane w województwach: mazowieckim, dolnośląskim, wielkopolskim i śląskim. Niezmiennie do najsłabszej grupy pod względem działalności eksportowej należały trzy województwa wschodnie: podlaskie, lubelskie i warmińsko-mazurskie.

\section{Podsumowanie}

W niniejszym opracowaniu, opierając się na sprawozdawczości GUS i nawiązując do koncepcji europejskiego badania demografii przedsiębiorstw, dokonano oceny międzywojewódzkiego zróżnicowania rozwoju przedsiębiorczości w okresie po 
akcesji Polski do Unii Europejskiej. Przyjęte na potrzeby opracowania zaproponowane wskaźniki dotyczyły trzech wymiarów przedsiębiorczości: skłonności do podejmowania działalności gospodarczej, działalności innowacyjnej oraz wyników finansowych, w tym działalności eksportowej.

W ciągu całego analizowanego okresu w rankingu województw pod względem wybranych wskaźników przedsiębiorczości najczęściej najwyższe noty uzyskiwało województwo mazowieckie oraz wielkopolskie, śląskie i małopolskie. Natomiast najniższe lokaty często notowano w przypadku województw podlaskiego i warmińsko-mazurskiego, świętokrzyskiego oraz zachodniopomorskiego.

Najwyższy dynamikę wartości wskaźników stwierdzono w przypadku wskaźników finansowych w zakresie działalności eksportowej, przychodów z całokształtu działalności przedsiębiorstw, wyniku finansowego brutto. W każdym z województw średnio przedsiębiorstwa uzyskiwały coraz lepsze wyniki finansowe, w tym coraz to wyższy dodatni wynik finansowy brutto - przychody z całokształtu działalności podmiotów przewyższały poniesione koszty (największy wzrost odnotowano w województwach: kujawsko-pomorskim, lubelskim i łódzkim).

W badanym okresie na ogół w województwach liczba jednostek wyrejestrowanych była niższa od liczby jednostek nowo zarejestrowanych (liczba kandydatów na przedsiębiorców) i bilans rejestracji podmiotów w rejestrze REGON był dodatni. W większości województw (w tym między innymi w podlaskim, kujawsko-pomorskim, lubelskim) stwierdzono rosnącą wartość wskaźnika wyrażającego relację podmiotów nowo zarejestrowanych do podmiotów wyrejestrowanych, co może świadczyć o coraz to większej skłonności do wyboru ścieżki przedsiębiorczej niż rezygnacji z tej ścieżki.

Natomiast w większości województw skłonność do działań prorozwojowych, aktywności przedsiębiorców w sferze działań innowacyjnych i inwestowania w innowacje w ciągu badanych lat znacznie się zmniejszyła (zwłaszcza w kujawsko-pomorskim, śląskim, warmińsko-mazurskim).

W wielu województwach można było zaobserwować zróżnicowany poziom, dynamikę i kierunek zmian wartości wskaźników charakteryzujących wybrane wymiary przedsiębiorczości. Nierównomierny rozwój poszczególnych wymiarów przedsiębiorczości stwierdzono między innymi co do województw lubelskiego i podkarpackiego, dla których mocną stroną była skłonność przedsiębiorstw do działań innowacyjnych (relatywnie wysokie odsetki przedsiębiorstw ponoszących nakłady na innowacje i wdrażających innowacje), natomiast słabszą stroną efekty finansowe, w tym działalność eksportowa.

Różnice w dynamice oraz nierównomierny rozwój poszczególnych charakterystyk przedsiębiorczości wpłynęły na poprawę pozycji niektórych województw w rankingu — na przykład lubelskiego i małopolskiego (szczególnie pod względem skłonności do rejestracji własnej działalności gospodarczej oraz skłonności do działań innowacyjnych). 
W przekroju województw w analizowanym przedziale czasowym utrzymała się duża dysproporcja i duży stopień koncentracji przestrzennej w wielkości eksportu, nakładów finansowych na działalność innowacyjną — budżetu na innowacje w przedsiębiorstwach oraz w wielkości przychodów z całokształtu działalności gospodarczej. Dla tych charakterystyk otrzymano najwyższe wartości wskaźników dyspersji. Najmniejsze zróżnicowanie międzywojewódzkie wystąpiło pod względem odsetka przedsiębiorstw innowacyjnych oraz odsetka przedsiębiorstw, które poniosły nakłady na innowacje oraz pod względem wskaźnika rentowności.

W porównaniu do sytuacji w pierwszych latach badanego przedziału czasowego nastąpiło zmniejszenie zróżnicowania między województwami pod względem wartości wyniku finansowego brutto na 1 przedsiębiorstwo, wartości eksportu dokonanego przez podmioty z udziałem kapitału zagranicznego na 1 mieszkańca oraz udziału przychodów netto ze sprzedaży produktów innowacyjnych w przychodach netto ze sprzedaży ogółem.

\section{Bibliografia}

Bartosiewicz, S., Stańczyk, E. (2018). Wybrane aspekty sytuacji społeczno-gospodarczej ściany wschodniej w porównaniu z resztą Polski w latach 2004-2016. Część IV — przedsiębiorczość. Studia i Prace WNEiZ US, 54/3, 8-23. DOI: 10.18276/sip.2018.54/3-01.

Bhaskaran, S. (2006). Incremental Innovation and Business Performance: Small and Medium-Size Food Enterprises in a Concentrated Industry Environment. Journal of Small Business Management, 44, 1, 64-80. https://doi.org/10.1111/j.1540-627X.2006.00154.x.

Carland, J.W., Hoy, F., Boulton, W.R. et al. (1984). Differentiating entrepreneurs from small business owners: A conceptualization. Academy of Management Review, 9, 354-359.

Chmieliński, P. (2006). Wspieranie przedsiębiorczości w działalności gospodarczej małych i średnich przedsiębiorstw w Polsce. W M. Strużycki (red.). Przedsiębiorczość w teorii i praktyce. Warszawa: Szkoła Główna Handlowa.

Cieślik, J. (2014). Przedsiębiorczość, polityka, rozwój. Warszawa: Wydawnictwo Akademickie SEDNO.

Cieślik, J. (red.) (2014). Raport o stanie przedsiębiorczości w Warszawie. Warszawa: Stołeczne Forum Przedsiębiorczości. Data dostępu: 13.07.2020, https://www.kozminski.edu.pl/fileadmin/ wspolne_elementy/Jednostki/CPrzedsiebiorczosci/Publikacje/Przedsiebiorczosc_lokalna/ Cieslik_Raport_o_stanie_przedsiebiorczosci_2014.pdf.

Cole, A.H. (1959). Business Enterprise in its Social Setting. Cambridge, MA: Harvard University Press, reprinted in Hébert, R.F., Link, A.N. (2007), Historical Perspectives on the Entrepreneur. Foundations and Trends ${ }^{\circledR}$ in Entrepreneurship, 2, 4, 261-408. Data dostępu: 13.07.2020, http://dx.doi.org/10.1561/0300000008.

Drucker, P.F. (1992). Innowacja i przedsiębiorczość. Praktyka i zasady. Warszawa: Wydawnictwo PWE.

Drucker, P.F. (2004). Natchnienie i fart, czyli innowacja i przedsiębiorczość. Warszawa: Wydawnictwo Studio Emka.

Gaweł, A. (2007). Ekonomiczne determinanty przedsiębiorczości. Poznań: Wydawnictwo Akademii Ekonomicznej.

Knight, F. (1921). Risk, Uncertainty and Profit. Boston: Houghton Mifflin. Data dostępu: 13.07.2020, https://fraser.stlouisfed.org/files/docs/publications/books/risk/riskuncertaintyprofit.pdf.

Ekonomia - Wroclaw Economic Review 26/, 2020

(C) for this edition by CNS 
Krajowa Strategia Rozwoju Regionalnego 2030 (2019). Ministerstwo Funduszy i Polityki Regionalnej. Data dostępu: 13.07.2020, https:/www.gov.pl/web/fundusze-regiony/krajowa-strategia-rozwoju-regionalnego.

Medina, E.V.C., Morales, L.E.I. (2013). Growing Impact Analysis Of Pymes Developed Under a Business Incubation Scheme: A Case Study. Revista Internacional Administración \& Finanzas (RIAF), 6, 3, 85-94.

Piecuch, T. (2010). Przedsiębiorczość. Podstawy teoretyczne. Warszawa: Wydawnictwo C.H. Beck. Przedsiębiorstwa niefinansowe powstałe w latach 2013-2017 (2019). Warszawa: GUS.

Potocki, A. (2000). Wspótczesne tendencje w zarządzaniu - teoria i praktyka. Chrzanów: Wyższa Szkoła Przedsiębiorczości i Marketingu.

Schumpeter J.A. (1934), Theory of Economic Development: An Inquiry into Profits, Capital, Credit, Interest, and the Business Cycle, London: Oxford University Press.

Schumpeter, J.A. (1960). Teoria rozwoju gospodarczego. Warszawa: PWN.

Skowronek-Mielczarek, A. (2003). Znaczenie sektora małych i średnich przedsiębiorstw w polskiej gospodarce. W A. Skowronek-Mielczarek (red.). Przedsiębiorstwo-przedsiębiorczość-rynek: 50-lecie pracy Mariana Strużyckiego. Warszawa: SGH.

Stańczyk, E., Stańczyk, P. (2017). Development of entrepreneurship in Lower Silesian voivodship after accession of Poland to the European Union. W L. Olszewski (red.). Entrepreneurship and regional development Wrocław: Wydawnictwo Naukowe Atla2, 119-136.

Strategia na rzecz Odpowiedzialnego Rozwoju do roku 2020 (z perspektywą do 2030 r.) (2017). Ministerstwo Funduszy i Polityki Regionalnej. Data dostępu: 13.07.2020, https://www.gov.pl/ web/fundusze-regiony/informacje-o-strategii-na-rzecz-odpowiedzialnego-rozwoju.

Strużycki, M. (red.) (2002). Zarządzanie małym i średnim przedsiębiorstwem. Uwarunkowania europejskie, Warszawa: Diffin.

Wybrane wskaźniki przedsiębiorczości w latach 2013-2017 (2019). Warszawa: GUS. 